Sains Malaysiana 50(8)(2021): 2167-2178

http://doi.org/10.17576/jsm-2021-5008-03

\title{
Agro-ecological Characterization of Vermicomposted Sewage Sludge from Municipal and Poultry Enterprise Wastewater Treatment Plants
}

(Pencirian Agro-ekologi Lumpur Kumbahan Vermikompos daripada Perbandaran dan Loji Rawatan Sisa Air Perusahaan Penternakan)

\author{
Diyana Dermendzhieva, Toncho Dinev, Gergana Kostadinova, Georgi Petkov \& Georgi BeEV*
}

\begin{abstract}
The purpose of this study was to make an agro-ecological characterization of vermicompost (VC) produced from sewage sludge (SS). As a substrate, SS from municipal and poultry meat processing enterprise wastewater treatment plants (MTP and PTP, respectively) was utilized. The substrates were vermicomposted by Red Californian earthworm (Lumbricus rubellus) for 120 days. For VC quality assessment, 19 physicochemical and 6 microbiological parameters were used. The evaluation of physicochemical parameters was done according to ISO standard methods and microbiological analysis-by plating $1 \mathrm{~mL}$ of sample dilutions on selective, chromogenic culture medium sheets. It was found that the vermicompost from MTP (VC-M) had higher levels of EC, mineral elements ( $N, P$ and $K$ compounds in forms available to plants), heavy metals ( $\mathrm{Mn}, \mathrm{Cu}, \mathrm{Zn}, \mathrm{Cr}, \mathrm{Ni}, \mathrm{Pb}, \mathrm{Cd}$ ) and coliforms, and lower levels of $\mathrm{pH}$, TOC, C/N ratio, Fe, total plate count (TPC), Enterobacteriaceae and Salmonella spp. counts compared to VC from PTP (VC-P). During the vermicomposting process, the substrates from both wastewater treatment plants (TPS) showed similar trends towards decrease in $\mathrm{pH}, \mathrm{TOC}, \mathrm{N}-\mathrm{NH}_{4}^{+}$, $C / N$ ratio, TPC, coliforms, E. coli, Enterobacteriaceae and Salmonella spp. counts, whereas the opposite trends were established for EC, TKN, N-NO- TP, $\mathrm{P}_{2} \mathrm{O}_{5}$, TK, and $\mathrm{K}_{2} \mathrm{O}$ values. The vermicomposting had a negligible effect on heavy metal concentrations. In the final substrates E. coli were not detected, while the bacterial spore forms (Clostridium perfringens) were not eliminated. The final substrates cannot be used as fertilizers or soil amendments because of the presence of Salmonella spp. and C. perfringens over the permissible limits according to EU and Bulgarian regulations.
\end{abstract}

Keywords: Lumbricus rubellus; physicochemical and microbiological parameters; sewage sludge; vermicompost

\section{ABSTRAK}

Tujuan kajian ini adalah untuk membuat pencirian agro-ekologi vermikompos (VC) yang dihasilkan daripada enap cemar kumbahan (SS). Sebagai substrat, SS daripada loji pengolahan air sisa perusahaan pemprosesan daging perbandaran dan unggas (MTP dan PTP) digunakan. Substrat dikomposkan oleh cacing tanah California Merah (Lumbricus rubellus) selama 120 hari. Untuk penilaian kualiti VC, 19 parameter fizikokimia dan 6 mikrobiologi digunakan. Penilaian parameter fizikokimia dilakukan mengikut kaedah piawaian ISO dan analisis mikrobiologi dengan meletakkan $1 \mathrm{~mL}$ pelarutan sampel pada kepingan medium kultur kromogen terpilih. Didapati bahawa vermikompos daripada MTP (VC-M) mempunyai tahap EC yang lebih tinggi, unsur mineral (sebatian N, P dan K dalam bentuk yang tersedia untuk tanaman), logam berat $(\mathrm{Mn}, \mathrm{Cu}, \mathrm{Zn}, \mathrm{Cr}, \mathrm{Ni}, \mathrm{Pb}, \mathrm{Cd})$ dan koliform, dan tahap pH, TOC, C/N ratio yang lebih rendah, Fe, jumlah plat keseluruhan (TPC), Enterobacteriaceae dan Salmonella spp. kiraan berbanding VC dari PTP (VC-P). Semasa proses vermikompos, substrat daripada kedua-dua loji rawatan air sisa (TP) menunjukkan kecenderungan serupa terhadap penurunan $\mathrm{pH}, \mathrm{TOC}, \mathrm{N}_{-} \mathrm{NH}_{4}^{+}, \mathrm{C} / \mathrm{N}$ ratio, TPC, coliforms, E. coli, Enterobacteriaceae dan Salmonella spp. penting, sedangkan arah aliran yang berlawanan telah ditetapkan untuk nilai EC, TKN, $N-N_{3}^{-}, T P, P_{2} O_{5}, T K$ dan $K_{2} O$. Pengkomposan mempunyai kesan yang tidak dapat diabaikan pada kepekatan logam berat. Pada substrat akhir E. coli tidak dikesan, sementara bentuk spora bakteria (Clostridium perfringens) tidak dihilangkan. Substrat akhir tidak boleh digunakan sebagai baja atau perubahan tanah kerana adanya Salmonella spp. dan C. perfringens melebihi had yang dibenarkan mengikut peraturan EU dan Bulgaria.

Kata kunci: Lumbricus rubellus; parameter fizikokimia dan mikrobiologi; sisa kumbahan; vermikompos 


\section{INTRODUCTION}

The wastewater treatment plants in the EU discharge about $14 \mathrm{Mt}$ of sludge per year. If not treated properly, they can be a significant source of high concentrations of organic pollutants and heavy metals and their potential accumulation in soils (DG Env. 2009). In 2019, 169 municipal TPs and over 100 local TPs in the food industry operated in Bulgaria generating approximately 164000 t sewage sludge (dry matter) per year. About $50 \%$ of that amount is used in agriculture as fertilizer without preliminary stabilization, $30 \%$ are temporarily stored and $20 \%$ are landfilled (Statistical Yearbook 2019). All disposal routes followed the National strategic plan for sludge management of MTPs (NSPSM 2014), Directive 86/278/EEC and national legislation (Regulation 2017). The use of sewage sludge (SS) for agricultural fertilization is a growing practice worldwide following the guidelines of the modern concepts of the circular economy, where the wastes should be viewed as resources (Pitombo et al. 2015). Environmental issues related to recycling of sewage sludge on land include the risk of nutrient leaching, impacts on soil biodiversity and greenhouse gas emissions. Contamination of soils, water, and crops with human pathogens has also been an important study subject (Ayusho et al. 1996; Gerba \& Smith 2005; Navarro et al. 2009).

For the sewage sludge to be safely used in agriculture, methods for its treatment, which are environmentally friendly, fast and cost-effective, are sought. Because the sludge is very rich in organic elements and microorganisms, a suitable method for their treatment is vermicomposting, which leads to stabilization of the organic waste materials through the joint action of earthworms and microorganisms in the substrate (Fanny et al. 2015; Kumaresan et al. 2016; Pathma \& Sakthivel 2012; Sharma et al. 2009). The vermicomposting has several advantages over other methods used for sewage sludge treatment: the earthworms transform the organic part of the sewage sludge in their intestines, and expel a partially stabilized product (vermicompost) with nutrients important for the plants $(\mathrm{N}, \mathrm{P}, \mathrm{K}, \mathrm{Ca})$ in more soluble and available to plants forms (Braga et al. 2017; Iwai et al. 2013); there is also a physical effect of the worms on the sewage sludge, expressed in its loosening and subsequent aeration, mixing, grinding and microbial decomposition (Gómez-Brandón et al. 2014; Haiba et al. 2014; Pathma \& Sakthivel 2012) so that the produced VC has lower weight, moisture content and unpleasant odors than SS (Bożym 2016).
The potential of earthworms to stabilize the sewage sludge was described by many authors, who found that various earthworms have a different potential in terms of their ability to convert the organic matter in SS to organic fertilizer in VC (Bartkowska et al. 2019; Gupta \& Garg 2008; Reddy et al. 2012; Soobhany et al. 2017; Suthar 2009). However, the experimental results regarding the ability of earthworms to affect the heavy metal concentrations are rather contradictory (Azizi et al. 2013; Kujavska et al. 2019; Sinha et al. 2010).

There are no scientific data about the vermicompost quality produced by earthworms from municipal or industrial sewage sludge. Based on the mentioned facts, this study aimed to evaluate the quality of the vermicompost, produced from the sludge of municipality wastewater treatment plant as fertilizer and compare it with that from poultry meat processing enterprise wastewater treatment plant.

\section{Materials AND Methods}

\section{SEWAGE SLUDGE}

SS used in the experiment originated from two different types treatment plants (TPs) - Municipal TP (MTP, SS-M) and Poultry Meat Processing Enterprise TP (PTP, SS-P). The TPs are located in Stara Zagora district, Bulgaria. MTP $\left(42^{\circ} 425^{\prime} \mathrm{N}\right.$ and $\left.25^{\circ} 634^{\prime} \mathrm{E}\right)$ treats the domestic (about $90 \%$ ), industrial (about 10\%) and surface wastewater (WW) from town of Stara Zagora (136,000 inhabitants). This is the most modern MTP in the country (in operation since 2011), with capacity equivalent to 100,000 people, an average WW rate of 970 L per second (3173.8 tons dry matter /DM/ per year). The PTP treats WW from a poultry meat processing plant situated nearby Kolarovo village $\left(42^{\circ} 426^{\prime} \mathrm{N}\right.$ and $\left.25^{\circ} 634^{\prime} \mathrm{E}\right)$ with a capacity equivalent to 500 inhabitants and average WW rate less than $10 \mathrm{~L}$ per second (about $500 \mathrm{~kg}$ DM of per year). The wastewater contains water from the washing of the inventory and the premises, waste from bird cuts and domestic fecal water from the personnel.

\section{EARTHWORMS}

For the sewage sludge composting, Red Californian earthworms (Lumbricus rubellus) were used as their populations are developing successfully in a moderately mild climate such as in Bulgaria, moreover, they are easily raised in laboratory conditions. The earthworms were collected from a Bulgarian licensed private earthworm farm. 


\section{EXPERIMENTAL DETAILS}

Two $10 \mathrm{~kg}$ samples of fresh sewage sludge (1-day old) from both TPs were collected and placed into 4 plastic containers ( $5 \mathrm{~kg}$ each): two negative controls - SS-M (from MTP) and SS-P (from PTP), without earthworms and two experimental - VC-M and VC-P, with 100 Red Californian earthworms (length 6-8 cm, weight 5-8 g). Before the implementation of earthworms, the preliminary decomposition of raw samples was performed for 20 days at aerobic conditions to pass the thermophilic phase and prevent earthworm mortality. All the containers were kept in the dark at $25 \pm 2{ }^{\circ} \mathrm{C}$ for 120 days of vermicomposting. For the normal growth and feeding of the earthworms in the experimental containers, an optimal sludge layer thickness of $50-60 \mathrm{~cm}$ and $75-80 \%$ moisture of the substrate was provided. The moisture regimen during vermicomposting was maintaining by spraying water once or twice a week. Substrate samples were collected from the control and experimental containers on the $1^{\text {st }}, 30^{\text {th }}, 60^{\text {th }}, 90^{\text {th }}$ and $120^{\text {th }}$ days of the experimental period.

\section{PARAMETERS AND METHODS FOR ANALYSIS PHYSICOCHEMICAL PARAMETERS}

The analyses of the monitored 19 parameters of that group were performed as follows: pH - ISO 10390, by $\mathrm{pH}$-meter Lab 850 in 1/5 (w/v) aqueous solution; electrical conductivity (EC) - EN 11265, by Tetra Con 325; moisture content (dry matter) of sludge and vermicompost - the samples were dried at $105{ }^{\circ} \mathrm{C}$ up to constant weight for the determination of the following parameters: total organic carbon (TOC) (ISO 14235); total Kjeldahl nitrogen

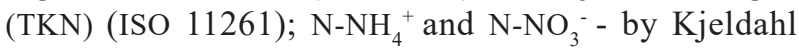
method; total phosphorus (Total P) - by ISO 11263; phosphates $\left(\mathrm{P}_{2} \mathrm{O}_{5}\right)$ - by spectrophotometric method with stannous chloride and UV-VIS spectrophotometer JENWAY 6705; total potassium (TK) - by ISO 11047 with an AAS; extractable potassium $\left(\mathrm{K}_{2} \mathrm{O}\right)$ - by ammonium acetate extractable method after extracting the sample; $\mathrm{C}: \mathrm{N}$ ratio - by calculation based on the measured values of $\mathrm{C}$ and $\mathrm{N}$; heavy metals concentrations $(\mathrm{Cu}, \mathrm{Fe}, \mathrm{Zn}, \mathrm{Mn}$, $\mathrm{Ni}, \mathrm{Cd}, \mathrm{Cr}$ and $\mathrm{Pb}$ ), acid decomposed - by ISO 15586 with an AAS (AAnalyst/800 Perkin-Elmer). All measurement and analyses were run in triplicate.

\section{MICROBIOLOGICAL PARAMETERS}

In the present study, the total plate count (TPC), indicator microorganisms (coliforms, Escherichia coli, Enterobacteriaceae) and pathogens (Salmonella spp.) were determined by preparation of serial ten-fold dilutions from SS/VC in sterile saline $(1: 10,1: 100,1: 100)$. One
$\mathrm{mL}$ of sample solutions or appropriate dilutions was transferred on selective, chromogenic culture medium sheets (Rida ${ }^{\circledR}$ Count Total; Rida ${ }^{\circledR}$ Count E. coli/Coliform; Rida ${ }^{\circledR}$ Count Salmonella/Enterobacteriaceae, R-Biopharm AG, Germany). The sheets were inoculated in triplicate, incubated at $35{ }^{\circ} \mathrm{C}$ for $24-48 \mathrm{~h}$ and the colonies were counted. The specific microorganisms formed colonies of different colors on the specific test cards. The results are expressed in $\mathrm{CFU} / \mathrm{g}$. The presence of $C$. perfringens was determined after transferring of $1 \mathrm{~mL}$ from the diluted samples in tubes, containing nutrient broth with $2 \%$ glucose and $0.5 \mathrm{~g}$ solid paraffin, then the content of the tubes was heated in a water bath at $85^{\circ} \mathrm{C}$ for $15 \mathrm{~min}$. After cooling, the inoculated tubes were incubated at $30{ }^{\circ} \mathrm{C}$ for 7 days. The results are expressed as the presence of spore forms $/ 1 \mathrm{~g}$. The presence of $C$. perfringens was confirmed after plating $0.1 \mathrm{~mL}$ from sample solution on Tryptose Sulphite Cycloserine Agar (TSC, HiMedia, India). Cultural characteristics were observed under anaerobic conditions after incubation at $35-37{ }^{\circ} \mathrm{C}$ for $18-24 \mathrm{~h}$.

\section{AGRO-ECOLOGICAL QUALITY ASSESSMENT OF VERMICOMPOST}

The produced vermicompost was assessed at two levels as followed: a) National level - based on 6 heavy metals content $(\mathrm{Cu}, \mathrm{Zn}, \mathrm{Cr}, \mathrm{Ni}, \mathrm{Pl}$ and $\mathrm{Cd})$ and 3 microbiological parameters (Salmonella spp., E. coli and Clostridium perfringens) according to Bulgarian legislation (Regulation 2017); b) EU level - based on 5 heavy metals content $(\mathrm{Cu}, \mathrm{Zn}, \mathrm{Ni}, \mathrm{Pl}$, and $\mathrm{Cd})$ according to Directive 86/278/EEC.

\section{STATISTICAL ANALYSIS}

All data were analyzed by statistical software and data analysis tool XLSTAT, Version 2016.02, Addinsoft.

\section{RESULTS AND DISCUSSION}

\section{PHYSICOCHEMICAL PARAMETERS (pH)}

There were no significant changes in $\mathrm{pH}$ values of the control substrates during the observation period, while in both VCs $\mathrm{pH}$ values decreased significantly after the $30^{\text {th }}$ day of the vermicomposting and reached their minimum on the $120^{\text {th }}$ day (Table 1). Garg et al. (2006) explained the $\mathrm{pH}$ reduction during vermicomposting with separating $\mathrm{CO}_{2}$ and organic acids due to microbial metabolism as well as with the presence of $\mathrm{NO}_{3}{ }^{-}$and $\mathrm{NO}_{2}^{-}$ions, which are weak bases causing ionic acidity. However, the final product from MTP had lower $\mathrm{pH}$ compared to PTP and both products had lower acidity (1.08-1.21 times) than the controls. 
TABLE 1. Physicochemical characteristics of sewage sludge and vermicompost (mean $\pm \mathrm{SD} ; \mathrm{n}=3$ )

\begin{tabular}{|c|c|c|c|c|c|c|}
\hline \multirow{2}{*}{ Parame-ters } & \multirow{2}{*}{ Subs-trate } & \multicolumn{5}{|c|}{ Control days } \\
\hline & & 1 & 30 & 60 & 90 & 120 \\
\hline \multirow{5}{*}{$\mathrm{pH}\left(\mathrm{H}_{2} \mathrm{O}\right)$} & SS-M & $7.03 \pm 0.01^{\mathrm{c}}$ & $7.02 \pm 0.01^{\mathrm{C}}$ & $6.59 \pm 0.01^{\mathrm{Dc}}$ & $7.05 \pm 0.01^{\mathrm{E}}$ & $7.00 \pm 0.01$ \\
\hline & VC-M & $7.04 \pm 0.01^{\text {cdef }}$ & $5.60 \pm 0.01^{\mathrm{Cc}}$ & $5.56 \pm 0.01^{\mathrm{Dd}}$ & $5.27 \pm 0.01 \mathrm{Ee}$ & $5.78 \pm 0.01^{\mathrm{f}}$ \\
\hline & SS-P & $7.30 \pm 0.01^{\mathrm{a}}$ & $7.24 \pm 0.01$ & $7.27 \pm 0.01^{\mathrm{C}}$ & $7.32 \pm 0.01$ & $7.35 \pm 0.01^{\mathrm{a}}$ \\
\hline & VC-P & $7.31 \pm 0.02^{\text {acde }}$ & $7.21 \pm 0.01^{\mathrm{a}}$ & $6.96 \pm 0.01^{\mathrm{Cc}}$ & $6.40 \pm 0.01^{\mathrm{d}}$ & $6.81 \pm 0.01^{\mathrm{e}}$ \\
\hline & SS-M & $1289.3 \pm 0.6^{\text {cdef }}$ & $1416.4 \pm 0.5^{\mathrm{Cc}}$ & $2170.9 \pm 0.4^{\mathrm{Dd}}$ & $3150.4 \pm 0.5^{\mathrm{Ee}}$ & $3985.7 \pm 0.6^{\mathrm{Ff}}$ \\
\hline \multirow{2}{*}{$\mathrm{EC}\left(\mu \mathrm{Scm}^{-1}\right)$} & VC-M & $1290.3 \pm 1.5^{\mathrm{cdef}}$ & $2471.3 \pm 0.5^{\mathrm{Cc}}$ & $3090.7 \pm 0.3^{\mathrm{Dd}}$ & $5730.7 \pm 0.3^{\mathrm{Ee}}$ & $7450.6 \pm 0.5^{\mathrm{Ff}}$ \\
\hline & SS-P & $2233.5 \pm 0.5^{\mathrm{efgh}}$ & $2781.4 \pm 0.6^{\mathrm{Ce}}$ & $3165.4 \pm 0.5^{\mathrm{f}}$ & $3316.7 \pm 0.3^{\mathrm{g}}$ & $4170.4 \pm 0.6^{\mathrm{h}}$ \\
\hline \multirow{5}{*}{$\begin{array}{l}\text { TOC } \\
\left(\mathrm{gkg}^{-1}\right)\end{array}$} & VC-P & $2234.0 \pm 1.0^{\text {efgh }}$ & $3009.7 \pm 0.6^{\mathrm{Ce}}$ & $3350.3 \pm 0.6^{\mathrm{f}}$ & $4850.4 \pm 0.6^{\mathrm{g}}$ & $6580.7 \pm 0.4^{\mathrm{h}}$ \\
\hline & SS-M & $233.3 \pm 0.4^{\mathrm{a}}$ & $233.0 \pm 0.9$ & $231.7 \pm 0.9^{\mathrm{A}}$ & $230.9 \pm 0.8^{\mathrm{A}}$ & $228.7 \pm 0.7^{\mathrm{Ca}}$ \\
\hline & VC-M & $233.5 \pm 0.5^{\mathrm{acbd}}$ & $230.5 \pm 0.5^{\mathrm{a}}$ & $220.6 \pm 0.4^{\mathrm{Ac}}$ & $224.9 \pm 0.3^{\mathrm{Ab}}$ & $201.8 \pm 0.3^{\mathrm{Cd}}$ \\
\hline & SS-P & $304.5 \pm 0.8^{\mathrm{a}}$ & $304.0 \pm 0.2^{\mathrm{C}}$ & $303.0 \pm 0.1^{\mathrm{D}}$ & $303.6 \pm 0.3^{\mathrm{E}}$ & $301.2 \pm 0.6^{\mathrm{Fa}}$ \\
\hline & VC-P & $304.7 \pm 0.6^{\text {bcde }}$ & $297.7 \pm 0.3^{\mathrm{Cc}}$ & $287.8 \pm 0.4^{\mathrm{Dd}}$ & $290.4 \pm 0.5^{\mathrm{Eb}}$ & $267.6 \pm 0.4^{\mathrm{Fe}}$ \\
\hline \multirow{4}{*}{ TKN $\left(\mathrm{gkg}^{-1}\right)$} & SS-M & $20.6 \pm 0.7$ & $20.0 \pm 0.5$ & $21.0 \pm 0.4^{\mathrm{A}}$ & $21.2 \pm 0.4^{\mathrm{B}}$ & $22.3 \pm 0.3^{\mathrm{B}}$ \\
\hline & VC-M & $20.8 \pm 0.3^{\text {bcd }}$ & $21.2 \pm 0.3$ & $22.8 \pm 0.3^{\mathrm{Ac}}$ & $23.3 \pm 0.2^{\mathrm{Bb}}$ & $25.5 \pm 0.1^{\mathrm{Bd}}$ \\
\hline & SS-P & $10.7 \pm 0.4^{\mathrm{a}}$ & $10.4 \pm 0.2^{\mathrm{B}}$ & $10.8 \pm 0.3^{\mathrm{A}}$ & $11.3 \pm 0.2^{\mathrm{A}}$ & $12.0 \pm 0.1^{\mathrm{Ca}}$ \\
\hline & VC-P & $10.3 \pm 0.3^{\mathrm{ab}}$ & $11.3 \pm 0.2^{\mathrm{Ba}}$ & $11.9 \pm 0.1^{\mathrm{Aa}}$ & $12.5 \pm 0.4^{\mathrm{Ab}}$ & $14.8 \pm 0.2^{\mathrm{Cb}}$ \\
\hline \multirow{4}{*}{$\begin{array}{l}\mathrm{N}-\mathrm{NH}_{4}^{+} \\
\left(\mathrm{gkg}^{-1}\right)\end{array}$} & SS-M & $2.48 \pm 0.5$ & $2.46 \pm 0.01$ & $2.43 \pm 0.1$ & $2.31 \pm 0.2$ & $1.98 \pm 0.2^{\mathrm{A}}$ \\
\hline & VC-M & $2.46 \pm 0.4^{\mathrm{a}}$ & $2.42 \pm 0.03$ & $2.10 \pm 0.08$ & $1.90 \pm 0.2$ & $1.09 \pm 0.03^{\mathrm{Aa}}$ \\
\hline & SS-P & $1.16 \pm 0.08$ & $1.15 \pm 0.09$ & $1.13 \pm 0.1$ & $1.06 \pm 0.06$ & $0.96 \pm 0.05^{\mathrm{C}}$ \\
\hline & VC-P & $1.15 \pm 0.07^{\mathrm{c}}$ & $1.12 \pm 0.03$ & $0.98 \pm 0.02$ & $0.83 \pm 0.09$ & $0.58 \pm 0.05^{\mathrm{Cc}}$ \\
\hline \multirow{4}{*}{$\mathrm{N}-\mathrm{NO}_{3}^{-}\left(\mathrm{gkg}^{-1}\right)$} & SS-M & $0.027 \pm 0.001^{\mathrm{ab}}$ & $0.030 \pm 0.002$ & $0.036 \pm 0.002^{\mathrm{Aa}}$ & $0.038 \pm 0.003^{b}$ & $0.051 \pm 0.003^{\mathrm{Cb}}$ \\
\hline & VC-M & $0.029 \pm 0.001^{\mathrm{abc}}$ & $0.035 \pm 0.001^{\mathrm{b}}$ & $0.052 \pm 0.003^{\mathrm{Ab}}$ & $0.081 \pm 0.017^{\mathrm{a}}$ & $0.122 \pm 0.003^{\mathrm{Cc}}$ \\
\hline & SS-P & $0.014 \pm 0.002^{\mathrm{abc}}$ & $0.017 \pm 0.002^{\mathrm{Bc}}$ & $0.023 \pm 0.002^{\mathrm{Aa}}$ & $0.030 \pm 0.002^{\mathrm{Ab}}$ & $0.036 \pm 0.002^{\mathrm{Bb}}$ \\
\hline & VC-P & $0.015 \pm 0.003^{\mathrm{acd}}$ & $0.026 \pm 0.001^{\mathrm{Ba}}$ & $0.038 \pm 0.002^{\mathrm{Aa}}$ & $0.048 \pm 0.004^{\mathrm{Ac}}$ & $0.075 \pm 0.003^{\mathrm{Bd}}$ \\
\hline \multirow{4}{*}{$\mathrm{C} / \mathrm{N}$ ratio } & SS-M & $11.3 \pm 0.7$ & $11.7 \pm 0.2^{\mathrm{A}}$ & $11.1 \pm 0.2^{\mathrm{A}}$ & $10.9 \pm 0.2^{\mathrm{B}}$ & $10.3 \pm 0.2^{\mathrm{B}}$ \\
\hline & VC-M & $11.2 \pm 0.7$ & $10.9 \pm 0.1^{\mathrm{A}}$ & $9.67 \pm 0.1^{\mathrm{A}}$ & $9.65 \pm 0.1^{\mathrm{B}}$ & $7.91 \pm 0.01^{\mathrm{B}}$ \\
\hline & SS-P & $28.5 \pm 1.2^{\mathrm{a}}$ & $29.2 \pm 0.5^{\text {B }}$ & $28.1 \pm 0.7^{\mathrm{A}}$ & $26.9 \pm 0.5^{\mathrm{A}}$ & $25.1 \pm 0.2^{\mathrm{Ca}}$ \\
\hline & VC-P & $29.6 \pm 1.3^{\mathrm{bcd}}$ & $26.3 \pm 0.5^{\text {в }}$ & $24.2 \pm 0.2^{\mathrm{Ac}}$ & $23.2 \pm 0.7^{\mathrm{Ab}}$ & $18.1 \pm 0.2^{\mathrm{Cd}}$ \\
\hline \multirow{4}{*}{$\begin{array}{l}\text { Total P } \\
\left(\mathrm{gkg}^{-1}\right)\end{array}$} & SS-M & $12.3 \pm 0.3^{\mathrm{a}}$ & $12.5 \pm 0.6$ & $12.8 \pm 0.3^{\mathrm{A}}$ & $13.2 \pm 0.4^{\mathrm{A}}$ & $13.8 \pm 0.2^{\mathrm{Aa}}$ \\
\hline & VC-M & $12.1 \pm 0.2^{\mathrm{ac}}$ & $13.0 \pm 0.2^{\mathrm{a}}$ & $13.9 \pm 0.2^{\mathrm{Ac}}$ & $14.6 \pm 0.3^{\mathrm{Ac}}$ & $15.3 \pm 0.3^{\mathrm{Ac}}$ \\
\hline & SS-P & $7.74 \pm 0.2^{\mathrm{a}}$ & $7.80 \pm 0.2$ & $7.92 \pm 0.3$ & $8.12 \pm 0.1$ & $8.22 \pm 0.1^{\mathrm{Aa}}$ \\
\hline & VC-P & $7.72 \pm 0.2^{\mathrm{a}}$ & $7.90 \pm 0.3$ & $8.27 \pm 0.3$ & $8.61 \pm 0.3$ & $9.32 \pm 0.3^{\mathrm{Aa}}$ \\
\hline \multirow{4}{*}{$\begin{array}{l}\mathrm{P}_{2} \mathrm{O}_{5} \\
\left(\mathrm{gkg}^{-1}\right)\end{array}$} & SS-M & $0.83 \pm 0.02^{\mathrm{a}}$ & $0.84 \pm 0.01$ & $0.86 \pm 0.03$ & $0.91 \pm 0.01^{\mathrm{Ca}}$ & $0.95 \pm 0.02^{\mathrm{Ba}}$ \\
\hline & VC-M & $0.84 \pm 0.03^{\mathrm{ac}}$ & $0.85 \pm 0.02$ & $0.94 \pm 0.02^{\mathrm{a}}$ & $1.08 \pm 0.04^{\mathrm{Cc}}$ & $1.14 \pm 0.05^{\mathrm{Ba}}$ \\
\hline & SS-P & $0.58 \pm 0.05$ & $0.58 \pm 0.02$ & $0.59 \pm 0.02^{\mathrm{A}}$ & $0.63 \pm 0.02^{\mathrm{B}}$ & $0.65 \pm 0.03^{\text {В }}$ \\
\hline & VC-P & $0.58 \pm 0.04^{\mathrm{ab}}$ & $0.62 \pm 0.01$ & $0.71 \pm 0.02^{\mathrm{Aa}}$ & $0.84 \pm 0.02^{\mathrm{Bb}}$ & $0.99 \pm 0.01^{\mathrm{Bb}}$ \\
\hline \multirow{4}{*}{$\begin{array}{l}\mathrm{TK} \\
\left(\mathrm{gkg}^{-1}\right)\end{array}$} & SS-M & $1.26 \pm 0.12^{\mathrm{a}}$ & $1.25 \pm 0.1$ & $1.26 \pm 0.07$ & $1.28 \pm 0.1^{\mathrm{a}}$ & $1.31 \pm 0.2$ \\
\hline & VC-M & $1.28 \pm 0.08$ & $1.24 \pm 0.06$ & $1.30 \pm 0.1$ & $1.34 \pm 0.2$ & $1.45 \pm 0.1$ \\
\hline & SS-P & $0.61 \pm 0.08$ & $0.61 \pm 0.04$ & $0.62 \pm 0.04$ & $0.64 \pm 0.03^{\mathrm{A}}$ & $0.72 \pm 0.01$ \\
\hline & VC-P & $0.59 \pm 0.06^{\mathrm{c}}$ & $0.78 \pm 0.2$ & $0.84 \pm 0.1$ & $0.90 \pm 0.05^{\mathrm{Ac}}$ & $1.09 \pm 0.2$ \\
\hline \multirow{4}{*}{$\begin{array}{l}\mathrm{K}_{2} \mathrm{O} \\
\left(\mathrm{gkg}^{-1}\right)\end{array}$} & SS-M & $0.36 \pm 0.02^{\mathrm{a}}$ & $0.36 \pm 0.03$ & $0.38 \pm 0.03$ & $0.38 \pm 0.04$ & $0.40 \pm 0.02^{\mathrm{a}}$ \\
\hline & VC-M & $0.36 \pm 0.02^{\mathrm{a}}$ & $0.37 \pm 0.02$ & $0.40 \pm 0.01$ & $0.46 \pm 0.03$ & $0.54 \pm 0.05^{\mathrm{a}}$ \\
\hline & SS-P & $0.19 \pm 0.03^{\mathrm{ab}}$ & $0.19 \pm 0.04$ & $0.21 \pm 0.02$ & $0.22 \pm 0.02^{\mathrm{Ab}}$ & $0.25 \pm 0.01^{\mathrm{Aa}}$ \\
\hline & VC-P & $0.18 \pm 0.02^{\mathrm{ac}}$ & $0.20 \pm 0.04$ & $0.24 \pm 0.01^{\mathrm{a}}$ & $0.30 \pm 0.02^{\mathrm{Ac}}$ & $0.34 \pm 0.02^{\mathrm{Aa}}$ \\
\hline
\end{tabular}

SS-M - sewage sludge (control) and VC-M - vermicompost from MTP; SS-P - sewage sludge (control) and VC-P - vermicompost from PTP; Differences in the values within rows are significant at: $\mathrm{P}<0.05$-aa, bb; $\mathrm{P}<0.01$-cc; $\mathrm{P}<0.001$-dd, ee, ff, gg, hh; Differences between values within columns are significant at $\mathrm{P}<0.05-\mathrm{AA}, \mathrm{BB} ; \mathrm{P}<0.01-\mathrm{CC}$; $\mathrm{P}<0.001$-DD, EE, FF 


\section{ELECTRICAL CONDUCTIVITY (EC)}

During the experimental period, all substrates demonstrated a trend towards increase in the EC value. This change is mostly related to the decreased $\mathrm{pH}$ and moisture. On one hand, acidification creates conditions for a higher amount of freely available minerals $\left(\mathrm{P}, \mathrm{NH}_{3}\right.$, $\mathrm{K})$ and ions to dissolve in the substrate water. On the other hand, dehydration of the material also leads to an increase in the salts concentration per unit solution. Kaviraj and Sharma (2003) and Ludibeth et al. (2012) reported similar to our results.

\section{TOTAL ORGANIC CARBON (TOC)}

TOC concentrations remained almost constant in the SS-M and SS-P, while in the VCs decreased during the period. Such reduction was due to the fact that a part of TOC was lost as $\mathrm{CO}_{2}$ because of the consumption of the available carbon as a source of energy by the earthworms and the microorganisms in the substrate. Tripathi and Bhardwaj (2004) also established higher TOC loss in earthworm-inoculated vermicomposts than in negative controls. At equal TOC concentrations in the initial substrates, the differences between SS (controls) and VC (vermicomposting) occurred after the $30^{\text {th }}$ day and reached maximum levels on the $120^{\text {th }}$ day. Based on the results it could be assumed that despite the different composition of the solid waste from the two treatment plants, the processes of transformation of carbon compounds during vermicomposting were similar. The results obtained are supported by those of other authors (Khwairakpam \& Bhargava 2009; Malinska et al. 2016; Singh et al. 2014; Suthar 2009) who reported even a larger loss of carbon (up to $45 \%$ ) during vermicomposting of municipal or industrial wastes than in our study (14$16 \%)$.

\section{TOTAL KIELDAHAL NITROGEN (TKN), ${\mathrm{N}-\mathrm{NH}_{4}^{+}}^{+}$AND N-NO}

TKN and $\mathrm{N}^{-\mathrm{NO}_{3}}{ }_{3}^{-}$content increased in the final products compared to the initial substrates. The presence of earthworms in VC-M and VC-P led to bigger changes in all nitrogen parameters than in the substrates without earthworms. The observed differences between various forms of $\mathrm{N}$ came from the metabolic activity of earthworms and microorganisms as well as changes in the condition of the substrates (moisture, $\mathrm{pH}$ ) during the experimental period caused by their transformation (immobilization/ denitrification). Khwairakpam and Bhargava (2009) pointed out that earthworms' activity enriched the nitrogen profile of the vermicompost through microbially mediated nitrogen transformation, mucus secretion and excretion of nitrogenous wastes (feces). An increase

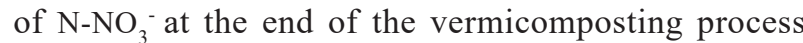
corresponded to decrease in $\mathrm{N}_{-} \mathrm{NH}_{4}^{+}$because of its nitrification by microorganisms in the substrates. The greater VC acidification compared to that of the SS also contributes to the greater nitrogen retention, since $\mathrm{N}_{2}$ is lost as volatile ammonia at high $\mathrm{pH}$ values (Garg et al. 2006).

Another aspect is the concentration of all forms of nitrogen in the SS-M and VC-M which were by 1.86 to 2.02 times higher than those in SS-P and VC-P. The data analysis showed that municipal wastes were much richer in nitrogen compounds than the waste from the poultry meat enterprise. The TKN results obtained for VC-M are similar to those reported by Ludibeth et al. (2012) and Sangwan et al. (2008); lower than the data of Kaviraj and Sharma (2003), Khwairakpam and Bhargava (2009), Suthar (2009), and higher than the results of Haiba et al. (2014).

\section{C/N RATIO}

A slight decrease in this ratio was observed in both controls mainly due to the weak microbial activity and with a more pronounced reduction in VCs. In this regard, Ndegwa and Thompson (2000) commented that the presence of earthworms in the substrate leads to higher organic carbon oxidation (part as $\mathrm{CO}_{2}$ ), mucus production, excreted nitrogen with feces, compared to the substrate without earthworms and as a result, the $\mathrm{C} / \mathrm{N}$ ratio decreased. Kaviraj and Sharma (2003), Khwairakpam and Bhargava (2009), and Sangwan et al. (2008) also found a similar trend whereas other authors reported an increase in $\mathrm{C} / \mathrm{N}$ ratio during composting and vermicomposting (Azizi et al. 2013; Malinska et al. 2016; Soobhany et al. 2015).

Numerous surveys determined the $\mathrm{C} / \mathrm{N}$ ratio as a very heterogeneous parameter, which is influenced by SS composition, earthworm species used, duration of vermicomposting, environmental conditions, and other factors (Kaviraj \& Sharma 2003; Malinska et al. 2016; Sangwan et al. 2008; Suthar 2009).

It is well known that plants cannot assimilate nitrogen when the $\mathrm{C} / \mathrm{N}$ ratio is less than 1:20 (Edwards \& 
Bohlen 1996). According to Senesi (1989), a decline in the $\mathrm{C} / \mathrm{N}$ ratio to less than 1:20 indicates an advanced degree of organic matter stabilization and reflects a satisfactory degree of maturity of organic wastes. Based on that, the data obtained showed a high degree of organic matter stabilization in the SS-M, VC-M, and VC-P at the end of the experimental period (an exception was the SS-P where this ratio exceeded 1:20) (Table 1).

\section{TOTAL P AND $\mathrm{P}_{2} \mathrm{O}_{5}$}

The content of both parameters increased by the end of the vermicomposting in all substrates - to a lesser extent in SS compared to VCs (Table 1). At the end of the survey, Total $\mathrm{P}$ and $\mathrm{P}_{2} \mathrm{O}_{5}$ concentrations were higher in SS-M compared to SS-P and in VC-M compared to VC$\mathrm{P}$. The extent of Total $\mathrm{P}$ and $\mathrm{P}_{2} \mathrm{O}_{5}$ increase was different for the substrates tested. The data clearly show that mineralization of phosphorus organic matter proceeded more efficiently in substrates with earthworms, compared to those without. In this connection, Gosh et al. (1999) underlined that vermicomposting can be an efficient technology for the transformation of unavailable forms of phosphorus to forms available for the plants through bacterial and fecal phosphatase activity of earthworms. A similar trend of Total P increase during vermicomposting was reported by Azizi et al. (2013), Haiba et al. (2014), Khwairakpam and Bhargava (2009), Malinska et al. (2016), Tripathi and Bhardwaj (2004), while Bajsa et al. (2005) and Boruszko (2016) observed an opposite trend.

\section{TOTAL K (TK) AND $\mathrm{K}_{2} \mathrm{O}$}

The TK and $\mathrm{K}_{2} \mathrm{O}$ contents, similarly to the phosphorus compounds, were higher in the substrates from MTP than in those from PTP. Both parameter values increased in all substrates during the monitored period. Azizi et al. (2013), Khwairakpam and Bhargava (2009), and Malinska et al. (2016) also established a positive trend of potassium concentration in the VC compared to the untreated substrate, in contrast to data reported by Haiba et al. (2014) and Sangwan et al. (2008).

The results obtained show that vermicomposting provides more favorable conditions for mineralization of organic potassium compared to controls, in line with Khwairakpam and Bhargava (2009) and Sharma (2003), who emphasized that acid production by gut microflora was the main mechanism for stabilizing insoluble potassium in the substrate.

HEAVY METALS (Fe, Mn, Cu, Zn, Cr, Ni, Pb, Cd)

Heavy metal concentrations in the negative controls (SS$\mathrm{M}$ and SS-P) and final products (VC-M and VC-P) were almost equal (Table 2). The results obtained showed two main aspects. First, the content of the monitored elements was different in the substrates from both TPs. The Mn, $\mathrm{Cu}, \mathrm{Zn}, \mathrm{Cr}, \mathrm{Ni}, \mathrm{Pb}$, and $\mathrm{Cd}$ contents were higher (from 1.16 times for $\mathrm{Ni}$ to 80.8 times for $\mathrm{Pb}$ ) in $\mathrm{SS}$ and $\mathrm{VC}$ from MTP compared to PTP. Only the Fe concentration was higher in SS-P and VC-P. It was due to the specificity and composition of waste in the poultry enterprise that contained more organic substances and required the utilization of larger amounts of coagulant $\left(\mathrm{Fe}_{2} / \mathrm{SO}_{4} /{ }_{3}\right)$. The second aspect referred to the heavy metals content in substrates from the same TP. In practice, metal levels did not change during the experiment. Castillo et al. (2010) who established slightly variation (2.8-9.2\%) of the heavy metals content (Fe, Mn, $\mathrm{Zn}, \mathrm{Cu}$ ) between produced compost and vermicompost reported similar results to ours.

Some researchers published contradictory data. Suthar (2009) found that extractable metals (Fe, $\mathrm{Mn}, \mathrm{Cu}, \mathrm{Zn}, \mathrm{Pb})$ decreased markedly (2.4-20\%) in vermicomposted material. Sinha et al. (2010) reported up to a $19.2 \%$ decrease of $\mathrm{Cd}$ and $\mathrm{Pb}$ in $\mathrm{VC}$ compared to the untreated sludge. An even greater reduction (14.4$67.7 \%$ ) of the $\mathrm{Fe}, \mathrm{Mn}, \mathrm{Zn}, \mathrm{Pb}, \mathrm{Cu}$ amount in $\mathrm{VC}$ produced from municipal SS was found by Khwairakpam and Bhargava (2009). The authors explained this reduction by earthworm's activities and the accumulation of the metals in the earthworm body as there was no leaching of the cations by extra water drainage. Finally, they concluded that heavy metals could be completely removed from the sewage sludge during vermicomposting. Other researchers informed about the opposite trend: Increase in the heavy metals concentration in the VC compared to the initial SS (Hait \& Tare 2012; Malinska et al. 2016).

The cited data showed that the heavy metal content in the vermicompost was influenced by many and different factors-composition of the initial substance, species of earthworms used, duration of composting, and environmental conditions. 
TABLE 2. Content of heavy metals in sewage sludge and vermicompost $(n=3)$

\begin{tabular}{|c|c|c|c|c|c|}
\hline $\begin{array}{l}\text { Element } \\
\left(\mathrm{mgkg}^{-1}\right)\end{array}$ & $\mathrm{TP}$ & Initial SS & Final VC & SL & $\mathrm{SL}_{1}$ \\
\hline \multirow{2}{*}{$\mathrm{Fe}$} & M & $3971.9 \pm 0.7$ & $3971.8 \pm 1.2$ & \multirow{2}{*}{ - } & \multirow{2}{*}{ - } \\
\hline & $\mathrm{P}$ & $11695.9 \pm 0.8$ & $11694.6 \pm 0.7$ & & \\
\hline \multirow{2}{*}{ Mn } & M & $141.8 \pm 0.20$ & $141.7 \pm 0.17$ & \multirow{2}{*}{-} & \multirow{2}{*}{ - } \\
\hline & $\mathrm{P}$ & $57.2 \pm 0.25$ & $57.0 \pm 0.10$ & & \\
\hline \multirow[b]{2}{*}{$\mathrm{Cu}$} & M & $195.7 \pm 0.36$ & $195.5 \pm 0.44$ & \multirow[b]{2}{*}{1600} & \multirow[b]{2}{*}{$1000-1750$} \\
\hline & $\mathrm{P}$ & $11.2 \pm 0.29$ & $10.9 \pm 0.15$ & & \\
\hline \multirow[b]{2}{*}{$\mathrm{Zn}$} & M & $1119.7 \pm 0.58$ & $1119.0 \pm 1.0$ & \multirow[b]{2}{*}{3000} & \multirow[b]{2}{*}{$2500-4000$} \\
\hline & $\mathrm{P}$ & $71.6 \pm 0.38$ & $71.2 \pm 0.32$ & & \\
\hline \multirow[t]{2}{*}{$\mathrm{Cr}$} & M & $41.07 \pm 0.40$ & $41.03 \pm 0.45$ & \multirow{2}{*}{500} & \multirow{2}{*}{-} \\
\hline & $\mathrm{P}$ & $9.59 \pm 0.04$ & $9.44 \pm 0.15$ & & \\
\hline \multirow[b]{2}{*}{$\mathrm{Ni}$} & M & $20.11 \pm 0.08$ & $20.05 \pm 0.04$ & \multirow[b]{2}{*}{350} & \multirow[b]{2}{*}{$300-400$} \\
\hline & $P$ & $1.813 \pm 0.03$ & $1.797 \pm 0.01$ & & \\
\hline \multirow[b]{2}{*}{$\mathrm{Pb}$} & M & $26.57 \pm 0.31$ & $26.50 \pm 0.26$ & \multirow[b]{2}{*}{800} & \multirow[b]{2}{*}{$750-1200$} \\
\hline & $\mathrm{P}$ & $0.333 \pm 0.021$ & $0.320 \pm 0.020$ & & \\
\hline \multirow[t]{2}{*}{$\mathrm{Cd}$} & M & $3.810 \pm 0.010$ & $3.807 \pm 0.011$ & \multirow{2}{*}{30} & \multirow{2}{*}{$20-40$} \\
\hline & $P$ & $0.427 \pm 0.021$ & $0.423 \pm 0.015$ & & \\
\hline
\end{tabular}

M - Municipal Treatment Plant (TP), P - Poultry TP; SS - sewage sludge, VC - vermicompost; SL - Standard Limit according to Regulation (2017); $\mathrm{SL}_{1}$ - Standard Limit according to Directive 86/278/EEC

Depending on the amount, the elements in the substrates were arranged in the following descending order: in SS-M and VC-M $-\mathrm{Fe}>\mathrm{Zn}>\mathrm{Cu}>\mathrm{Mn}>\mathrm{Cr}>$ $\mathrm{Pb}>\mathrm{Ni}>\mathrm{Cd}$; in SS-P and VC-P - $\mathrm{Fe}>\mathrm{Zn}>\mathrm{Mn}>\mathrm{Cu}>$ $\mathrm{Cr}>\mathrm{Ni}>\mathrm{Cd}>\mathrm{Pb}$. Those arrangements fully or partly coincided with the ranking of the elements in other studies from Poland (Bartkowska et al. 2019; Boruszko 2016; Malinska et al. 2016) and India (Khwairakpam \& Bhargava 2009; Suthar 2009). It is noteworthy that in all SSs from different MTPs and vermicomposted final products, the greatest amount of $\mathrm{Fe}$ was followed by those of $\mathrm{Zn}$ and $\mathrm{Cu}$ and the lowest contents were those of $\mathrm{Pb}$ and Cd. Despite the observed tendency in the ranking of the heavy metals' amount in sludge and compost, it is difficult to make a definite conclusion at this stage. Further research is warranted to clarify all these aspects.

\section{MICROBIOLOGICAL PARAMETERS TOTAL PLATE COUNT (TPC)}

TPC values varied significantly between individual substrates (Table 3). In this aspect, initial sewage sludge from PTP had much more saprophytic microorganisms than MTP. A general tendency of strong TPC reduction in all substrates during vermicomposting was observed: 
SS-M by $92.1 \%$, SS-P by $87.1 \%$, VC-M by $99.9 \%$ and VC-P by $99.6 \%(\mathrm{P}<0.05)$. The decrease in the microbial load was time- and substrate-dependent. For the SS-M, TPC reduction was observed after the $60^{\text {th }}$ day and for the SS-P - after the $90^{\text {th }}$ day, while in both VCs it started after 30 days of vermicomposting. These events occurred at a different intensity for different substrates. In other studies, the reported results are significantly different from ours (Mushan et al. 2014; Singh \& Bhadauria 2012), suggesting that the decontamination processes depended on sludge composition, worms species used, and environmental conditions.

TABLE 3. Microbiological characteristics of sewage sludge and vermicompost (mean $\pm S D ; n=3$ )

\begin{tabular}{|c|c|c|c|c|c|c|}
\hline \multirow{2}{*}{ Parameters } & \multirow{2}{*}{$\begin{array}{l}\text { Subst- } \\
\text { rate }\end{array}$} & \multicolumn{5}{|c|}{ Control days } \\
\hline & & 1 & 30 & 60 & 90 & 120 \\
\hline \multirow{4}{*}{$\begin{array}{l}\text { Total plate } \\
\text { count, } \\
\text { CFUg } \\
\left(\times 10^{5}\right)\end{array}$} & SS-M & $38.0 \pm 9.5^{\mathrm{a}}$ & $37.5 \pm 2.0^{\mathrm{B}}$ & $33.9 \pm 1.7^{6 \mathrm{C}}$ & $33.3 \pm 2.8^{\mathrm{B}}$ & $3.00 \pm 4.50^{\mathrm{Ba}}$ \\
\hline & VC-M & $38.4 \pm 11.0^{\mathrm{a}}$ & $2.34 \pm 5.25^{5 \mathrm{Ba}}$ & $1.08 \pm 1.18^{\mathrm{Ca}}$ & $0.322 \pm 0.6^{\mathrm{Ba}}$ & $0.0454 \pm 0.456^{\mathrm{Ba}}$ \\
\hline & SS-P & $153.0 \pm 25.0^{\mathrm{b}}$ & $150.0 \pm 26.0$ & $143.0 \pm 15.0^{\mathrm{B}}$ & $23.7 \pm 2.5^{\mathrm{Bb}}$ & $19.7 \pm 2.1^{\mathrm{Bb}}$ \\
\hline & VC-P & $157.0 \pm 12.0^{\mathrm{b}}$ & $133.0 \pm 3.00$ & $29.3 \pm 1.5^{\mathrm{Bb}}$ & $1.53 \pm 0.21^{\mathrm{Bb}}$ & $0.583 \pm 3.512^{\mathrm{Bb}}$ \\
\hline \multirow{4}{*}{$\begin{array}{l}\text { Coliforms, } \\
\text { CFUg-1 } \\
\left(\times 10^{4}\right)\end{array}$} & SS-M & $6.17 \pm 3.51^{\mathrm{a}}$ & $6.15 \pm 3.91$ & $6.10 \pm 2.65^{\mathrm{C}}$ & $5.93 \pm 8.15^{\text {в }}$ & $5.73 \pm 4.73^{\mathrm{Ba}}$ \\
\hline & VC-M & $6.20 \pm 3.00^{\text {cde }}$ & $6.11 \pm 2.70$ & $0.917 \pm 0.702^{\mathrm{Cc}}$ & $0.520 \pm 0.100^{\mathrm{Bd}}$ & $0.233 \pm 0.252^{\mathrm{Be}}$ \\
\hline & SS-P & $3.97 \pm 0.21^{\mathrm{a}}$ & $3.90 \pm 0.11$ & $3.63 \pm 0.25^{\text {В }}$ & $3.47 \pm 0.15^{\mathrm{Ba}}$ & $3.17 \pm 0.15^{\mathrm{Ca}}$ \\
\hline & VC-P & $4.00 \pm 0.10^{\mathrm{efg}}$ & $3.74 \pm 0.26$ & $1.05 \pm 0.13^{\mathrm{Be}}$ & $0.78 \pm 0.033^{\mathrm{Bf}}$ & $0.22 \pm 0.02^{\mathrm{Cg}}$ \\
\hline \multirow{4}{*}{$\begin{array}{l}\text { E. coli, } \\
\text { CFU/g } \\
\left(\times 10^{2}\right)^{*}\end{array}$} & SS-M & $9.07 \pm 0.15^{\mathrm{b}}$ & $9.03 \pm 0.21^{\mathrm{B}}$ & $8.90 \pm 0.10^{\text {В }}$ & $8.60 \pm 0.36^{\mathrm{C}}$ & $7.33 \pm 0.15^{\mathrm{Db}}$ \\
\hline & VC-M & $9.10 \pm 0.20^{\mathrm{bcd}}$ & $7.80 \pm 0.26^{\mathrm{Bb}}$ & $4.50 \pm 0.60^{\mathrm{Bb}}$ & $0.01 \pm 0.006^{\mathrm{Cc}}$ & $0.0 \pm 0^{\mathrm{Dd}}$ \\
\hline & SS-P & $8.27 \pm 0.15^{\mathrm{ac}}$ & $8.23 \pm 0.31$ & $7.84 \pm 0.21^{\mathrm{Ba}}$ & $7.17 \pm 0.23^{\mathrm{Ca}}$ & $6.83 \pm 0.12^{\mathrm{Dc}}$ \\
\hline & VC-P & $8.30 \pm 0.10^{\text {def }}$ & $8.17 \pm 0.15$ & $3.60 \pm 0.26^{\mathrm{Bd}}$ & $0.05 \pm 0.001^{\mathrm{Ce}}$ & $0.0 \pm 0^{\mathrm{Df}}$ \\
\hline \multirow{4}{*}{$\begin{array}{l}\text { Enteroba- } \\
\text { cteriaceae, } \\
\mathrm{CFU} / 20 \mathrm{~g} \\
\left(\times 10^{3}\right)\end{array}$} & SS-M & $4.03 \pm 21^{\mathrm{a}}$ & $4.00 \pm 0.21$ & $3.37 \pm 0.42$ & $3.27 \pm 0.29^{\mathrm{Ba}}$ & $2.63 \pm 0.15^{\mathrm{Ba}}$ \\
\hline & VC-M & $4.07 \pm 0.15^{\mathrm{bcd}}$ & $3.97 \pm 0.32$ & $2.73 \pm 0.21^{\mathrm{b}}$ & $0.91 \pm 0.015^{\mathrm{Bc}}$ & $0.37 \pm 0.021^{\mathrm{Bd}}$ \\
\hline & SS-P & $44.7 \pm 3.51^{\mathrm{a}}$ & $44.0 \pm 2.65$ & $41.3 \pm 2.52^{\mathrm{B}}$ & $38.7 \pm 1.53^{\mathrm{C}}$ & $36.0 \pm 1.73^{\mathrm{Da}}$ \\
\hline & VC-P & $44.3 \pm 2.08^{\text {ef }}$ & $40.0 \pm 1.73$ & $35.7 \pm 2.08^{\mathrm{B}}$ & $8.07 \pm 1.53^{\mathrm{Ce}}$ & $4.17 \pm 2.52^{\mathrm{Df}}$ \\
\hline \multirow{4}{*}{$\begin{array}{l}\text { Salmonella } \\
\text { spp., } \\
\text { CFU/20g } \\
\left(\times 10^{3}\right)^{* *}\end{array}$} & SS-M & $2.23 \pm 0.15^{\mathrm{a}}$ & $2.20 \pm 0.36$ & $2.00 \pm 0.26$ & $1.78 \pm 0.15^{\mathrm{B}}$ & $0.57 \pm 0.12^{\mathrm{Ba}}$ \\
\hline & VC-M & $2.23 \pm 0.21^{\mathrm{b}}$ & $2.20 \pm 0.10$ & $1.93 \pm 0.15$ & $0.91 \pm 0.02^{\mathrm{Bb}}$ & $0.17 \pm 0.01^{\mathrm{Bb}}$ \\
\hline & SS-P & $21.3 \pm 3.06^{\mathrm{b}}$ & $21.0 \pm 1.00$ & $18.7 \pm 1.53$ & $17.3 \pm 0.58^{\mathrm{C}}$ & $1.50 \pm 2.00^{\mathrm{Bb}}$ \\
\hline & VC-P & $21.0 \pm 2.00^{\mathrm{b}}$ & $20.7 \pm 1.53$ & $17.0 \pm 2.0$ & $5.47 \pm 3.51^{\mathrm{Cb}}$ & $3.70 \pm 2.65^{\mathrm{Bb}}$ \\
\hline \multirow{4}{*}{$\begin{array}{l}\text { Clostridium } \\
\text { perfringens } \\
\text { CFUg }^{-1 * * *}\end{array}$} & SS-M & + & + & + & + & + \\
\hline & VC-M & + & + & + & + & + \\
\hline & SS-P & + & + & + & + & + \\
\hline & VC-P & + & + & + & + & + \\
\hline
\end{tabular}

SS-M - sewage sludge (control) and VC-M - vermicompost from Municipal TP SS-P - sewage sludge (control) and VC-P - vermicompost from Poultry TP Differences in the values within rows are significant at: $\mathrm{P}<0.05-$ aa, bb; $\mathrm{P}<0.01$ - cc; $\mathrm{P}<0.001-\mathrm{dd}$, ee, ff, gg Differences between values within columns are significant at $\mathrm{P}<0.05-\mathrm{AA}, \mathrm{BB} ; \mathrm{P}<0.01-\mathrm{CC}$; $\mathrm{P}<0.001-\mathrm{DD}$

*Norm - Most Probable Number (MPN) $\leq 100 / \mathrm{g} ;{ }^{* * N o r m}$ - Not allowed in $20 \mathrm{~g} ;{ }^{* * *}$ Norm - Most Probable Number $\leq 300 \mathrm{~g}^{-1}$ according to Regulation 2017; + C. perfringens number was over $300 \mathrm{CFU} \mathrm{g}^{-1}$ 


\section{COLIFORMS}

The number of coliforms varied within relatively narrow ranges (Table 3). The SS from MTP contained more coliforms than initial substrates from PTP. The same trend was maintained regarding the decontamination processes during the vermicomposting. As a whole, the reduction of coliforms number was not as clearly pronounced as that of TPC. Soobhany (2018) reported such partial reduction of total coliforms number after seven weeks of vermicomposting. On the contrary, Khwairakpam and Bhargava (2009) established a higher reduction of coliforms (99-99.9\%) in seven vermicomposting scenarios with different combinations of three worm species $-E$. fetida, E. eugeniae, and P. excavates. Hait and Tare (2012) also found a significantly reduced total coliforms level during vermicomposting using E. fetida. However, according to Aira et al. (2011) and Lalander et al. (2015), vermicomposting does not affect total coliforms number.

\section{E. COLI}

Initially, the presence of $E$. coli in all substrates was relatively equal. During the observation period, $E$. coli number decreased and reached $100 \%$ removal at the $120^{\text {th }}$ day for VC-M and VC-P $(\mathrm{P}<0.001)$. The same trend was maintained in controls, where the number of E. coli decreased by $19.2 \%$ for SS-M and by $17.4 \%$ for SS-P, respectively $(\mathrm{P}<0.05)$. Reddy et al. (2012) and Soobhany (2018) also reported the total removal of E. coli observed in our study. According to Aira et al. (2011) vermicomposting with Eisenia andrei reduced E. coli numbers to acceptable levels. Boruszko and Butarewicz (2015) reported considerable reduction of $E$. coli numbers (from $6.2 \times 10^{6}$ to $3.3 \times 10^{3}$ ) after six months of vermicomposting.

\section{ENTEROBACTERIACEAE}

The number of these bacteria varied in different ranges in the substrates from both TPs (Table 3 ). Their quantity was much higher in the initial substrates and final product from PTP than those from MTP. This could be explained by the different composition of organic waste from both TPs. Urban waste contains mostly feces and urine, while the waste from poultry meat processing enterprise, except the above-mentioned components, contains intestinal residuals with high microbial load, including Enterobacteriaceae. The vermicomposting causes a significant reduction for Enterobacteriaceae reaching 90.9 for VC-M and $90.6 \%$ for VC-P. The observed microbial reduction of the controls was 34.7 and $19.5 \%$ for SS-M and SS-P, respectively. These results demonstrated the role and importance of earthworms in the Enterobacteriaceae removal process from the substrates. The statistically significant differences in Enterobacteriaceae numbers were observed between SS-M and VC-M on the $90^{\text {th }}$ and $120^{\text {th }}$ day $(\mathrm{P}<0.05)$ and between SS-P and VC-P on the $60^{\text {th }}, 90^{\text {th }}$ and $120^{\text {th }}$ day of the measurement $(\mathrm{P}<0.05-\mathrm{P}<0.001)$. In the available literature, we found only one study concerning the effects of earthworms on Enterobacteriaceae (Aira et al. 2011), reporting that Enterobacteriaceae levels were not modified during vermicomposting with Eisenia andrei.

\section{SALMONELLA SPP}

Similarly to Enterobacteriaceae, the concentration of Salmonella spp. was higher in the sewage sludge from PTP than from MTP. This difference was also maintained for finished products but to varying extent (Table 3). A positive trend of the Salmonella spp. reduction during vermicomposting was observed. In the final substrates (SS-M, SS-P, VC-M, and VC-P) salmonellae concentration decreased by $74.4,93.0,92.4$, and $82.4 \%$, respectively $(\mathrm{P}<0.05)$. Eastman et al. (2001) and Hait and Tare (2012) also reported a similar trend. According to Soobhany (2018), earthworms eliminated Salmonella spp. in the substrate after 7 weeks of vermicomposting. Boruszko (2016) and Lalander et al. (2015) also reported the total elimination of Salmonella spp. during vermicomposting using E. eugeniae and L. rubellus, respectively.

\section{CLOSTRIDIUM PERFRINGENS}

Data analysis showed that the vermicomposting did not eliminate the spore forms from sewage sludge. The presence of Clostridium perfringens in the substrates tested exceeded $300 \mathrm{CFU} / \mathrm{g}$ during the entire survey (Table 3). These findings were in line with the results obtained by Aira et al. (2011) who used E. andrei for vermicomposting. Moreover, it was found that the gut of earthworms contained spore-forming bacteria from genus Clostridium and they could pass in vermicompost with the feces (Pathma \& Sakthivel 2012).

\section{AGRO-ECOLOGICAL ASSESSMENT OF VERMICOMPOST QUALITY}

To be used as organic fertilizers in agriculture, the sewage sludge and vermicompost must meet the requirements 
stipulated in national and EU legislation. The national-level assessment, carried out by six heavy metals, showed that the concentrations of all elements $(\mathrm{Cu}, \mathrm{Zn}, \mathrm{Cr}, \mathrm{Ni}, \mathrm{Pl}$ and $\mathrm{Cd}$ ) in the final substrates - SS-M, SS-P, VC-M and VC-P were under the limit of the relevant standard (Regulation 2017) (Table 2).

As the microbiological parameters (Salmonella spp., E. coli and C. perfringens) were concerned, only the E. coli number in vermicomposts from both TPs (VC-M and VC-P) was within the acceptable level $\left(\leq 100 \mathrm{MPNg}^{-1}\right)$ (Table 3 ). E. coli number in final sewage sludge (SS-M and SS-P), Salmonella spp. which are not allowed in $20 \mathrm{~g}$ of the substrates and $C$. perfringens were above the permissible standard limits (Tables 2 and 3 ).

On the EU level, the assessment based on five heavy metals $(\mathrm{Cu}, \mathrm{Zn}, \mathrm{Ni}, \mathrm{Pl}$, and $\mathrm{Cd})$ showed that the concentrations of measured elements in all final substrates (SS and VC) were under the permissible limits according to Directive 86/278/EEC.

Considering that the final evaluation of the substrates is based on the lowest assessment from all of the parameters investigated, it can be concluded that the sewage sludge and vermicompost from the municipal and poultry enterprise TPs cannot be used as fertilizers because they do not meet the regulatory requirements on the microbiological indicators defined in Bulgarian legislation (Regulation 2017).

\section{CONCLUSION}

Overall, the study showed that the vermicomposts produced from SS of both TPs had different physicochemical and microbial compositions. VC from municipal SS (VC-M) demonstrated higher concentration of $\mathrm{N}, \mathrm{P}, \mathrm{K}, \mathrm{Mn}, \mathrm{Cu}, \mathrm{Zn}, \mathrm{Cr}, \mathrm{Ni}, \mathrm{Pb}, \mathrm{Cd}$ compounds and coliforms compared to the $\mathrm{VC}$ from poultry enterprise SS (VC-P), that contained more TOC, $\mathrm{C} / \mathrm{N}$ ratio, $\mathrm{Fe}$, total plate count, Enterobacteriaceae and Salmonella spp. During vermicomposting of SS from both TPs, similar trends of decrease/increase in values of investigated parameters were observed. Vermicomposting did not affect the heavy metals content, totally reduced $E$. coli and did not eliminate $C$. perfringens in the final products. The vermicomposts produced did not meet the requirements for organic fertilizers in agriculture due to the presence of Salmonella spp. and C. perfringens over the permissible limits according to Bulgarian legislation.

\section{ACKNOWLEDGMENTS}

This work was supported by the Bulgarian Ministry of Education and Science under the National Research Programme 'Healthy Foods for a Strong Bio-Economy and Quality of Life' and National Program for Research 'Young Scientists and Postdoctoral Students' approved by DCM \# 577/17.08.2018.

\section{REFERENCES}

Aira, M., Gómez-Brandón, M., González-Porto, P. \& Domínguez, J. 2011. Selective reduction of the pathogenic load of cow manure in an industrial-scale continuousfeeding vermireactor. Bioresource Technology 102(20): 9633-9637.

Ayusho, M., Pascual, J.A., Garcia, C. \& Hremandez, T. 1996. Evaluation of urban wastes for agricultural use. Soil Science Plant Nutrition 42(1): 105-111.

Azizi, A.B., Lim, M.P.M., Noor, Z.M. \& Abdullah, N. 2013. Vermiremoval of heavy metal in sewage sludge by utilising Lumbricus rubellus. Ecotoxicology and Environmental Safety 90: 13-20.

Bartkowska, I., Biedka, P. \& Tałałaj, I.A. 2019. Analysis of the quality of stabilized municipal sewage sludge. Journal of Ecological Engineering 20(2): 200-208.

Bajsa, O., Nair, J., Mathew, K. \& Ho, G.E. 2005. Processing of sewage sludge through vermicomposting. In Water and Environment Management Series, edited by Mathew K. \& Nhapi I. UK: IWA Publishing London.

Boruszko, D. 2016. Determining the effectiveness in vermicomposting of sewage sludge and the attempt to increase the effectiveness by applying bacterial microorganisms. Journal of Ecological Engineering 17(3): 53-59.

Boruszko, D. \& Butarewicz, A. 2015. Impact of effective microorganisms bacteria on low-input sewage sludge treatment. Environment Protection Engineering 41(4): 83-96.

Bożym, M. 2016. Vermicomposting of sewage sludge. Chemik 70(10): 616-619.

Braga, F.M., Cardoso, P.H.S., Barbosa, M.H.C., Rodrigues, M.N., Sampaio, R.A. \& Fernandes, L.A. 2017. Chemical characterization of vermicompost of sewage sludge with different proportions of diatomaceous material. Revista Brasileira de Engenharia Agrícola e Ambiental 21(8): 519. 523.

Castillo, H., Hernández, A., Dominguez, D. \& Ojeda, D. 2010. Effect of californian red worm (Eeisenia foetida) on the nutrient dynamics of a mixture of semicomposted materials. Chilean Journal of Agricultural Research 70(3): 465-473. 
DG Env. 2009. Environmental, Economic and Social Impacts of the Use of Sewage Sludge on Land (Final Report). Study Contract. European Commission.

Directive 86/278/EEC. 1986. Council Directive of 12 June 1986 on the protection of the environment, and in particular of the soil, when sewage sludge is used in agriculture (86/278/ EEC). Official Journal of the European Community.

Eastman, B.R., Kane, P.N., Edwards C.A., Trytek, L., Gunadi, B., Sterner, A.L. \& Mobley, J.R. 2001. The effectiveness of vermiculture in human pathogen reduction for USEPA biosolids stabilization. Compost Science \& Utilization 9(1): 38-49.

Edwards, C.A. \& Bohlen, P.J. 1996. Biology and Ecology of Earthworms. Boundary Row, London: Chapman and Hall.

Fanny, S.R., Jorge, M.E., Mario, U.R. \& Cruz, M.Q. 2015. Degradation of sewage sludge from plant wastewater using vermicompost. International Journal of Modern Biological Research 4: 1-4.

Garg, P., Gupta, A. \& Satya, S. 2006. Vermicomposting of different types of waste using Eisenia foetida: A comparative study. Bioresource Technology 97(3): 391-395.

Gerba, C.P. \& Smith, J.E. 2005. Sources of pathogenic microorganisms and their fate during land application of wastes. Journal of Environmental Quality 34(1): 42-48.

Gómez-Brandón, M. \& Domínguez, J. 2014. Recycling of solid organic wastes through vermicomposting: Microbial community changes throughout the process and use of vermicompost as a soil amendment. Critical Reviews in Environmental Science and Technology 44(12): 12891312.

Gupta, R. \& Garg, V.K. 2008. Stabilization of primary sewage sludge during vermi-composting. Journal of Hazardous Materials 153(3): 1023-1030.

Iwai, C.B., Ta-Oun, M., Chuasavatee, T. \& Boonyotha, P. 2013. Management of municipal sewage sludge by vermicomposting technology: Converting a waste into a bio fertilizer for agriculture. International Journal of Environmental and Rural Development 4(1): 169-174.

Haiba, E., Ivask, M., Olle, L., Peda, J., Kuu, A, Kutti, S. \& Nei, L. 2014. Transformation of nutrients and organic matter in vermicomposting of sewage sludge and kitchen wastes. Journal of Agricultural Science 6(2): 114-118.

Hait, S. \& Tare, V. 2012. Transformation and availability of nutrients and heavy metals during integrated compostingvermicomposting of sewage sludge. Ecotoxicology and Environmental Safety 79: 214-224.

Kaviraj \& Sharma, S. 2003. Municipal solid waste management through vermicomposting employing exotic and local species of earthworms. Bioresource Technology 90(2): 169-173.

Khwairakpam, M. \& Bhargava, R. 2009. Vermitechnology for sewage sludge recycling. Journal of Hazardous Materials 161(2-3): 948-954.
Kujavska, J. \& Wojcik-Oliveira, K. 2019. Effect of vermicomposting on the concentration of heavy metals in soil with drill cuttings. Journal of Ecological Engineering 20(1): 152-157.

Kumaresan, K., Balan, R., Sridhar, A., Aravind, J., Kanmani, P. \& Global, J. 2016. An integrated approach of composting methodologies for solid waste management. Global Journal of Environmental Science and Management 2(2): 157-162.

Lalander, C.H., Komakech, A.J. \& Vinneràs, B. 2015. Vermicomposting as manure management strategy for urban small-holder animal farms - Kampala case study. Waste Management 39: 96-103.

Ludibeth, S.M., Marina, I.E. \& Vicenta, E.M. 2012. Vermicomposting of sewage sludge: Earthworm population and agronomic advantages. Compost Science \& Utilization 20(1): 11-17.

Malinska, K., Zabochnicka-Swiatek, M., Cáceres, R. \& Marfà, O. 2016. The effect of precomposted sewage sludge mixture amended with biochar on the growth and reproduction of Eisenia fetida during laboratory vermicomposting. Ecological Engineering 90: 35-41.

Mushan, L.C., Dama, L.B. \& Rao, K.R. 2014. Microbial analysis of tendu leaf litter vermicompost. International Science Journal 1(1): 75-80.

Navarro, I., Jiménez, B., Lucario, S. \& Cifuentes, E. 2009. Application of helminth ova infection dose curve to estimate the risks associated with biosolid application on soil Journal of Water and Health 7(1): 31-44.

Ndegwa, P.M. \& Thompson, S.A. 2000. Effect of C-to-N ratio on vermicomposting of biosolids. Bioresource Technology 75(1): 7-12.

NSPSM. 2014. National Strategic Plan for Sludge Management from Municipal Wastewater Treatment Plants on the Territory of the Republic of Bulgaria for the Period 2014-2020. Ministry of Environment and Water. Sofia, Bulgaria. pp. 32-55.

Pathma, J. \& Sakthivel, N. 2012. Microbial diversity of vermicompost bacteria that exhibit useful agricultural traits and waste management potential. Springer Plus 1(1): $1-19$.

Pitombo, L.M., Carmo, J.B., Maria, I.C, \& Andrade, C.A. 2015. Carbon sequestration and greenhouse gases emissions in soil under sewage sludge residual effects. Scientia Agricola 72(2): 147-156.

Reddy, S.A., Akila, S. \& Kale, R.D. 2012. Management of secondary sewage sludge by vermicomposting for use as soil amendment. Global Journal of Biotechnology and Biochemistry 7(1): 13-18.

Regulation. 2017. Regulation on the procedure and method of utilization of sludges from the waste water treatment by their use in agriculture. 
Sangwan, P., Kaushik, C.P. \& Garg, V.K. 2008. Vermiconversion of industrial sludge for recycling the nutrients. Bioresource Technology 99(18): 8699-8704.

Senesi, N. 1989. Composted materials as organic fertilizers. Science Total Environment 81-82: 521-524.

Sharma, K.S. 2003. Municipal solid waste management through vermicomposting employing exotic and local species of earthworms. Bioresource Technology 90(2): 169-173.

Sharma, S., Kumar, A., Singh, A.P. \& Vasudevan, P. 2009 Earthworms and vermitechnology - A review. Dynamic Soil Dynamic Plant 3(2): 1-12.

Sinha, R.K., Herat, S., Bharambe, G. \& Brahambhatt, A. 2010. Vermistabilization of (biosolids) by earthworms: Converting a potential biohazard destined for landfill disposal into a pathogen-free, nutritive and safe biofertilizer for farms. Waste Management and Research 28(10): 872-881.

Singh, D. \& Bhadauria, S. 2012. Quantitative and qualitative distribution of bacteria in vermicompost produced by different organic wastes. Nature Environment and Pollution Technology 11(2): 331-334.

Singh, A., Singh, R.V., Saxena, A.K., Shivay, Y.S. \& Nain, L. 2014. Comparative studies on composting efficiency of Eisenia foetida (SAVIGNY) and Perionyx excavatus (PERRIER). Journal of Experimental Biology and Agricultural Sciences 2(5): 508-517.

Soobhany, N. 2018. Preliminary evaluation of pathogenic bacteria loading on organic municipal solid waste compost and vermicompost. Journal of Environmental Management 206: 763-767.
Soobhany, N., Mohee, R. \& Garg, V.K. 2017. A comparative analysis of composts and vermicomposts derived from municipal solid waste for the growth and yield of green bean (Phaseolus vulgaris). Environmental Science and Pollution Research 24(12): 11228-11239.

Soobhany, N., Mohee, R. \& Garg, V.K. 2015. Experimental process monitoring and potential of Eudrilus eugeniae in the vermicomposting of organic solid waste in Mauritius. Ecological Engineering 84: 149-158.

Statistical Yearbook (SY). 2019. National Statistical Institute, Sofia, Republic of Bulgaria.

Suthar, S. 2009. Vermistabilization of municipal sewage sludge amended with sugarcane trash using epigeic Eisenia fetida (Oligohaeta). Journal of Hazardous Materials 163(1): 199206.

Tripathi, G. \& Bhardwaj, P. 2004. Comparative studies on biomass production, life cycles and composting efficiency of Eisenia fetida (Savigny) and Lampito mauriti (Kinberg). Bioresource Technology 92(3): 275-283.

Trakia University

Faculty of Agriculture

6000 Stara Zagora

Bulgaria

*Corresponding author; email: gbeev@abv.bg

Received: 25 March 2020

Accepted: 25 December 2020 